\title{
Diferente mas não indiferente: juízo e compaixão em Os 11,8-9; $13,2-14,1$
}

Orientadora: Maria de Lourdes Corrêa Lima

Mestranda: Patrícia de Moraes Mendes de Sousa

Área de Concentração: Teologia Bíblica

Linha de Pesquisa: Análise e Interpretação de Textos do Antigo e Novo Testamento

O presente trabalho estuda os textos de Os 11,8-9; 13,12-14,1. As perícopes foram selecionadas a partir do paradoxo instaurado entre elas. Os 11,8-9 apresenta uma reflexão de Deus diante da questão se Israel deve ou não ser destruído e que suspende o aniquilamento do povo. Dois capítulos depois, no último texto antes da promessa final do livro, Os 13,12-14,1, o mesmo Deus decreta a execução do castigo que levará à extinção do Reino do Norte. Com o intuito de tentarmos indicar como se coadunam as duas perspectivas, que implicam suspensão do juízo e sua afirmação, estabeleceremos elementos de aproximação e oposição entre os textos. Para tanto, serão considerados também os dados redacionais, a fim de elucidar a concatenação entre as duas perspectivas aparentemente contraditórias.

Palavras-chave: Teologia Bíblica. Antigo Testamento. Profetas pré-exílicos. Livro de Oseias. Juízo no Antigo Testamento. Compaixão de Deus. 